\title{
Counseling on Cardiovascular Behavioral Risk Factors within the Healthcare System: the CroHort Study
}

\author{
Vanja Crnica', Bojana Bolić ${ }^{2}$, Aleksandar Džakula ${ }^{2}$, Ksenija Vitale ${ }^{2}$ and Neda Pjevač \\ ${ }^{1}$ Zagreb Emergency Medical Center, Zagreb Croatia \\ ${ }^{2}$ University of Zagreb, School of Medicine, »Andrija Štampar« School of Public Health, Zagreb, Croatia
}

\begin{abstract}
A B S T R A C T
Eliminating four behavioral risk factors (tobacco use, physical inactivity, unhealthy diet and harmful use of alcohol) could contribute to a decrease of up to $80 \%$ in burden of non-communicable diseases, including cardiovascular diseases. Primary healthcare providers have a unique position within the healthcare system, which allows them to actively contribute to the prevention of cardiovascular behavioral risk factors (CVBRFs) by providing individual counseling. The aim of this article is to show the change in frequency and the effects of counseling on CVBRFs by healthcare providers between two periods: up until 2003 and between 2003 and 2008. Results, obtained within the CroHort study, show a low frequency and undesired effects of counseling within the healthcare system in both studied periods. This points to a lack of consistency with which the healthcare system tackles prevention of behavioral risk factors for cardiovascular diseases.
\end{abstract}

Key words: prevention, non-communicable disease, cardiovascular disease, counseling, primary healthcare

\section{Introduction}

Elimination of four behavioral risk factors: tobacco use, physical inactivity, unhealthy diet and harmful use of alcohol could contribute to a decrease of up to $80 \%$ in burden of heart attacks, stroke and diabetes mellitus ${ }^{1}$. It is particular lifestyle choices that affect health, namely cardiovascular health, in a large measure. The role of the healthcare providers is not only to provide cures but also to empower people and communities for health promotion and disease prevention ${ }^{2}$. A review article by Whitlock presents an abundance of research pointing that brief interventions, including counseling, integrated into routine primary care can effectively address the most common and important behavioral risk factors ${ }^{3}$. According to the Plan and Program of Measures for Healthcare in Croatia, all healthcare providers are to incorporate preventive activities into their everyday practices and for the adult population a specific emphasis is given to family medicine practices and visiting nurses ${ }^{4}$.

Individual practitioners who sign contracts with the Croatian Department of Health Insurance are the most common model of family medicine practice in the Croatian healthcare system, with $80 \%$ practices set up in this manner. In 2009 there were 2.305 family practice teams who had $77.5 \%$ of the population registered in their care. ${ }^{5}$ Family physicians should be among the healthcare providers who have a crucial role in disease prevention and health promotion. They have an immediate and continuous relationship with their patients and thus are ideally positioned to incorporate counseling as a preventive activity in their everyday practice ${ }^{6}$. On the other hand, the total number of visits registered in family physicians practices was $26,183.246$ but only 32.046 of those were systematic, periodical or control examinations for adults where counseling on cardiovascular behavioral risk factors could be provided 7 . The family physicians have an integrated approach to patients so preventive and curative activities often take place simultaneously without specified curriculums and guidelines being applied and the preventive activities mostly refer to secondary prevention ${ }^{6,8}$. 
The community nurses play an equally important role in counseling individuals, families and groups within the communities they live and work $\mathrm{in}^{9,10}$. A randomized control study showed that a common intervention by community nurses and nutritionist that included behavioral counseling and was aimed at decreasing multiple cardiovascular risk factors had positive effects on high risk patients $^{11}$.

Family physicians are freely chosen by patients, which supports a sense of confidentiality of the relationship, while the visiting nurses are allocated territorially and have an excellent knowledge of and a relationship with the entire community. Traditionally, the cooperation between family physicians and visiting nurses was encouraged as a means to yield the best results through a two-fold immediacy of contact - with both the individual and the community. Results of previous studies support this approach indicating that counseling by physicians and nurses is effective ${ }^{12}$.

The first Croatian Adult Health Survey (CAHS) in 2003 assessed risk factors for cardiovascular diseases. Preliminary analyses of the data showed that cardiovascular diseases were a great a burden and that both secondary and primary prevention were inadequate, even though all forms of prevention, including counseling are a proclaimed obligation of primary healthcare.

The aim of this article is to show the change in counseling on cardiovascular behavioral risk factors (CVBRFs) by healthcare providers as perceived and reported by the patients. We assessed the difference in received counseling reported in 2003 and that reported in 2008. Furthermore, we assessed the change in exposure to behavioral risk factors as a potential measure of effects of counseling within the healthcare system. As a targeted intervention program ${ }^{13}$ was just beginning to be implemented at the same time as data was collected in 2008 , we expect any change observed not to be attributable to that prevention program but to reflect the system's passive, automatic response to the burden of cardiovascular diseases.

\section{Subjects and Methods}

Data for this study was obtained through Croatian Adult Health Cohort Study (CroHort), designed as a repeated cross-sectional, cohort study looking into the determinants of health and various aspects of availability and accessibility of healthcare system in Croatia. A total of 3229 subjects were surveyed in both $2003^{14}$ and $2008^{15}$ and their results were interpreted as results of a single cohort.

We analyzed counseling on four behavioral risk factors: smoking, unhealthy diet, physical inactivity and harmful use of alcohol, that are common to all noncommunicable diseases, including cardiovascular diseases. ${ }^{1}$ Exposure to each of the particular behavioral risk factors was defined in accordance with the CroHort team and is described in »The Changing Pattern of Cardiovascular Risk Factors: the CroHort Study« by Poljičanin et al. ${ }^{16}$.
The availability of professional medical counsel was determined from responses to a question if the subjects have received counseling on that behavioral risk factor, where family physicians, other health care professionals, family members and others were listed as potential counselors. For the purpose of this study all the subjects who responded being counseled by either family physicians or other healthcare professionals were considered as the group that has received counseling within the healthcare system.

The initial sample of subjects for this study was the cohort of 3229 participants, but only those subjects who provided responses to all questions could finally be included in the analyses, and this number differed for each particular CVBRF.

All data was analyzed using SAS (version 9.1.3). We used the McNamar test to assess the significance of change in counseling and the significance of change of exposure to behavioral risk factors as a potential measure of the effects of counseling.

\section{Results}

The results are presented in two separate tables, the first addressing the change in counseling received and the second addressing the effects of counseling in terms of change in exposure to particular behavioral risk factors.

In Table 1. we presented results for reported frequencies of counseling within the health care system for the period prior to 2003 and the period between 2003 and 2008. Subjects were divided in two groups whose results were analyzed separately: the first group are subjects who reported as being exposed to that behavioral risk factor in 2003 and the second group comprises subjects who were not exposed to the particular behavioral risk factor in 2003. Counseling is separately analyzed for each of four cardiovascular risk behaviors.

We interpreted an increase in reported counseling as the desired effect - a positive outcome. That outcome was not universal. With respect to smoking, counseling increased significantly from the period prior to 2003 until the period between 2003 and 2008, regardless of subject's status as a smoker or a non-smoker. A positive outcome was also noted within the group of subjects that was adequately physically active. We found an increase in counseling within the healthcare system that was both significant and substantial, i.e. the frequency of counseling by healthcare professionals increased from $3 \%$ to $17 \%$, noted for the period until the year 2003 and the period between 2003 and 2008, respectively. Finally, a desired outcome in terms of counseling frequency was registered for the group of subjects who were not exposed to cardiovascular behavioral risk factor of harmful alcohol consumption: $2 \%$ of subjects were counseled in the period prior to 2003 and $7 \%$ in the period between 2003 and 2008.

In Table 2. we presented the exposure to cardiovascular behavioral risk factors for two groups of subjects those who have received counseling for the particular be- 
TABLE 1

COUNSELING RECEIVED WITHIN THE HEALTHCARE SYSTEM IN THE PERIOD UP UNTIL 2003 AND IN THE PERIOD BETWEEN 2003 AND 2008.

\begin{tabular}{|c|c|c|c|c|c|c|c|}
\hline \multirow{3}{*}{$\begin{array}{l}\text { Cardiovascular } \\
\text { behavioral risks }\end{array}$} & \multicolumn{7}{|c|}{ Health Care Professional Counseling } \\
\hline & \multirow[t]{2}{*}{$\begin{array}{l}\text { Exposure to risk } \\
\text { reported in } 2003 .\end{array}$} & \multicolumn{2}{|c|}{$\begin{array}{l}\text { Received counseling, } \\
\mathrm{n}(\%)\end{array}$} & \multicolumn{2}{|c|}{$\begin{array}{l}\text { Did not receive counseling, } \\
\mathrm{n}(\%)\end{array}$} & \multirow[t]{2}{*}{$\begin{array}{c}\text { Total } \\
\mathrm{n}\end{array}$} & \multirow[t]{2}{*}{$\mathrm{p}$} \\
\hline & & $\ldots-2003$ & 2003.-2008. & $\ldots-2003$ & 2003.-2008. & & \\
\hline \multirow[t]{2}{*}{ 1. Smoking } & Exposed & $167(43)$ & $197(51)$ & $220(57)$ & $190(49)$ & 387 & $* *$ \\
\hline & Not exposed & $22(25)$ & $37(42)$ & $67(75)$ & $52(58)$ & 89 & $* *$ \\
\hline \multirow[t]{2}{*}{ 2. Unhealthy diet } & Exposed & $121(27)$ & $135(31)$ & $320(73)$ & $306(69)$ & 441 & \\
\hline & Not exposed & $858(33)$ & $906(34)$ & $1781(67)$ & $1733(66)$ & 2639 & \\
\hline \multirow[t]{2}{*}{ 3. Physical inactivity } & Exposed & $354(34)$ & $309(30)$ & $686(66)$ & $731(70)$ & 1040 & $* *$ \\
\hline & Not exposed & $69(3)$ & $346(17)$ & $1941(97)$ & $1664(83)$ & 2010 & $* *$ \\
\hline \multirow[t]{2}{*}{ 4. Harmful use of alcohol } & Exposed & $47(42)$ & $31(28)$ & $65(58)$ & $81(72)$ & 112 & $* *$ \\
\hline & Not exposed & $27(2)$ & $95(7)$ & $1280(98)$ & $1212(93)$ & 1307 & $* *$ \\
\hline
\end{tabular}

* $\mathrm{p}<0.05$.

*** $\mathrm{p}<0.01$.

TABLE 2

CHANGE IN EXPOSURE TO BEHAVIOURAL RISK FACTORS ACCORDING TO COUNSELING RECEIVED IN THE PERIOD BETWEEN 2003 AND 2008

\begin{tabular}{|c|c|c|c|c|c|c|c|}
\hline \multirow{3}{*}{$\begin{array}{l}\text { Health Care Professional } \\
\text { Counseling in the period } \\
2003-2008\end{array}$} & & \multicolumn{4}{|c|}{ Cardiovascular behavioral risks } & \multirow{3}{*}{$\begin{array}{l}\text { Total, n } \\
(100 \%)\end{array}$} & \multirow{3}{*}{$\mathrm{p}$} \\
\hline & & \multicolumn{2}{|c|}{ Exposed, n(\%) } & \multicolumn{2}{|c|}{ Not exposed, n(\%) } & & \\
\hline & & 2003. & 2008. & 2003. & 2008 & & \\
\hline \multirow[t]{2}{*}{ 1. Smoking } & Received counseling & $197(63)$ & $249(79)$ & $118(37)$ & $66(21)$ & 315 & $* *$ \\
\hline & Did not receive counseling & $192(44)$ & $239(55)$ & $245(56)$ & $198(45)$ & 437 & $* *$ \\
\hline \multirow[t]{2}{*}{ 2. Unhealthy diet } & Received counseling & $135(13)$ & $114(11)$ & $906(87)$ & $927(89)$ & 1041 & \\
\hline & Did not receive counseling & $306(15)$ & $260(13)$ & $1733(85)$ & $1779(87)$ & 2039 & $*$ \\
\hline \multirow{2}{*}{$\begin{array}{l}\text { 3. Inadequate physical } \\
\text { activity }\end{array}$} & Received counseling & $309(47)$ & $510(78)$ & $347(53)$ & $146(22)$ & 656 & $* *$ \\
\hline & Did not receive counseling & $728(30)$ & $659(28)$ & $1662(70)$ & $1731(72)$ & 2390 & $* *$ \\
\hline \multirow[t]{2}{*}{ 4. Alcohol } & Received counseling & $31(25)$ & $68(54)$ & $95(75)$ & $58(46)$ & 126 & $* *$ \\
\hline & Did not receive counseling & $81(6)$ & $67(5)$ & $1215(94)$ & $1229(95)$ & 1296 & \\
\hline
\end{tabular}

$* \quad \mathrm{p}<0.05$.

$* * \mathrm{p}<0.01$.

havioral risk factor between years 2003 and 2008 and those who have not received counseling in the said period. We were interested in change in percentages of subjects exposed to particular behavioral risk factors as measured in years 2003 and 2008. A decrease in the percentage of subjects exposed to behavioral risk factor was desired, or positive outcome.

Significant positive changes were registered for the group of subjects who had reported not having been counseled on healthy dietary habits within the medical system - in 2003, $15 \%$ of those subjects maintained an unhealthy diet, while in 2008 there were $13 \%$ of subjects with an unhealthy diet. The only other desired outcome noted was for physical inactivity. A decrease in the percentage of subjects who were physically inactive was noted for the group of subjects who were not counseled within the healthcare system.

\section{Discussion and Conclusion}

The recorded change in counseling by primary healthcare providers shows a positive trend - counseling on smoking increased regardless of exposure to that risk and there was also an increase in counseling on physical inactivity and excessive alcohol consumption for the population not exposed to that particular risk. This positive trend is an affirmation of a thesis that, even though the system does not anticipate nor encourage primary healthcare providers as potential leaders in design and implementation of preventive programs ${ }^{17}$, counseling within the healthcare system still occurs as a passive, spontaneous response to the needs of the population. But the adequacy of such unsystematic approach is dubious; in spite of a positive trend noticed, the frequency of counseling remained below $50 \%$ for all categories of subjects, with the exception of counseling of $51 \%$ of counseling of sub- 
jects exposed to the risk of smoking in the latter period. An unexpected finding was that with respect to physical inactivity and alcohol consumption counseling decreased for the population exposed to those risks. Brotons et al. previously showed that it was secondary and not primary preventive measures for behavioral risk factors - such as counseling people who drink excessively or lead a sedentary life - that are identified by the healthcare providers as those that they integrate into their everyday practice ${ }^{8}$.

Another surprising finding was that percentages of subjects who made unhealthy behavioral choices increased among the group of subjects who reported to have received counseling. The frequencies of smokers, more physically inactive people, and more people excessively consuming alcohol increased. On the other hand, there were fewer subjects reporting as having an unhealthy diet and being physically inactive among the group of subjects who said that they have not received counseling within the healthcare system One potential explanation is, as previous studies have shown, that patients simply do not recognize or recall being counseled. ${ }^{18}$ These findings question the appropriateness and effectiveness of "spontaneous « counseling.

It is also in accordance with previous analyses within the CAHS study and literature, which showed that counseling to particular groups, such as the young and women, is limited ${ }^{19,20,21}$. Thus, counseling is often conducted for patients who already have a certain risk behavior, as a secondary preventive measure ${ }^{8,22}$ but not as a primary preventive measure ${ }^{23}$, and this constitutes a missed opportunity to counsel within the primary healthcare system. The finding that the counseling yielded results opposite from the desired outcome further contributes to a thesis that unorganized, »reflex « counseling is not adequate $^{24}$.

On the other hand, there are efforts to systematically approach NCD's, including cardiovascular diseases. In the period during which the CroHort was conducted several national programs were designed and implemented by the Ministry of Health and Social Security of Republic of Croatia $^{25}$ and the results presented here can also be considered a contribution to the evaluation of these projects, as one of them included mandatory systemic check-ups for the population over $50^{26}$ where counseling could have easily been integrated. But, to affect lifestyles with a goal of developing healthier behaviors a younger population must be addressed adequately, where again individual counseling within the healthcare system together with creating supportive environments (e.g. through legislation where there was recent example of a law restricting in-door smoking ${ }^{27}$ ) may contribute to effectively tackling the problem of behavioral risks to NCDs.

A limitation within the CroHort study is the size of the cohort, as the response rate of subjects who participated in the 2008 survey was relatively small. On the other hand, to the best of our knowledge, this is the only study in Croatia looking into availability of counseling on all four cardiovascular behavioral risk factors within the healthcare system as perceived by the users of that system, regardless of age and gender.

The perceived spontaneous increase of activity of healthcare providers shown in this paper speaks volumes about individual responsibility and devotion, yet it unfortunately also demonstrates a lack of organized approach to counseling within the system. Also, as the outcomes of counseling are mostly not positive, not only adequacy, but also effectiveness of an unstructured approach dependant of individual zeal becomes questionable. And the questions that arise are difficult to answer, as research about and evaluation of programs within the system is scarce.

\section{Acknowledgements}

The authors wish to thank all their colleagues from extended CASH and CroHort team. This manuscript is prepared within the project of the Ministry of Science, Education and Sports, Grant No. 108-1080135-0264

\section{R E F E R E N C E S}

1. WHO, 2008-2013 Action Plan for the Global Strategy for the Prevention and Control of Noncommunicable Diseases, accessed 15.06.2011. Available from: URL: www.who.int/nmh/Actionplan-PC-NCD-2008.pdf. - 2. WHO OTTAWA CHARTER, Ottawa Charter for Health Promotion. First International Conference on Health promotion (WHO, Ottawa, Canada, 1986). - 3. WHITLOCK EP, ORELANS CT, PENDER N, ALLAN J, Am J Prev Med, 22 (2002) 267. — 4. MZSS, Plan i program mjera zdravstvene zaštite iz obveznog zdravstvenog osiguranja, Narodne novine, 122 (2006), accessed 15.06.2011. Available from: URL: http://narodne-novine.nn.hr/default. aspx. - 5. HZJZ Croatian health service yearbook 2009, Accessed 15.06. 2011. Available from: URL: http://www.hzjz hr/publikacije/hzs_ljetopis/. - 6. KATIĆ M, JUREŠA V, BERGMAN-MARKOVIĆ B, JÜRKOVIĆ D, PREDAVEC S, HRASTINSKI M, BALEN B, PETRIC D, MAZZI B, TILJAK H, GMAJNIĆ R, DIMINIĆ-LISICA I, SIMUNOVIĆ R, JOVANOVIĆ A, VUKOVIĆ H, PRLJEVIĆ G, STEVANOVIĆ R, Acta med Croatica, 64 (2010) 443. - 7. DRŽAVNI ZAVOD ZA STATISTIKU, Državni statistički ljetopis 2009. Accessed 15.06.2011 Available from: URL: http://www.dzs.hr/Hrv Eng/ljetopis/2009/PDF/00-sadrzaj.pdf. - 8. BROTONS C, BJÖRKELŪND C, BULC M, CIURANA R, GODYCKI-CWIRKO M, JURGOVA E, KLOPPE P, LIONIS C, MIERZE-
CKI A, ROSA PIÑEIRO, PULLERITS L, SAMMUT MR, SHEEHAN M, TATARADZE R, THIREOS EA, VUCHAK J, Prev Med 40 (2005), 595. 9.WORLD HEALTH ORGANIZATION, REGIONAL OFFICE FOR EUROPE, Highlights on Health in Croatia (WHO, Copenhagen, 2000). - 10. MOJSOVIĆ Z (ed), Sestrinstvo u zajednici (Visoka zdravstvena škola, Zagreb, 2004). - 11. MA J, BERRA K, HASKELL WL, KLIEMAN L, HYDE S, SMITH MW, XIAO L, STAFFORD RS, Arch Intern Med 169 (2009) 1988 - 12. OCKENE JK, ADAMS A, HURLEY TG, WHEELER EV, HEBERT JR Arch Intern Med 159 (1999) 2198. — 13. PAVIĆ J, ŽUPANIĆ M, MUSIĆ MILANOVIĆ S, FIŠTER K, Coll Antropol 33 (Suppl 1) (2009) 81. - 14. VULETIĆ S, POLAŠEK O, KERN J, STRNAD M, BAKLAIĆ Ž, Coll Antropol 33 (Suppl 1) (2009) 3. - 15. IVIČEVIĆ UHERNIK A, VULETIĆ S, KERN J, DEČKOVIĆ-VUKRES V, MIHEL S; ERCEG M, PRISTAŠ I, Coll Antropol, 36 (Suppl 1) (2012) 3. - 16. POLJČANIN T, DŽAKULA A, MUSIC MILANOVIĆ S, ŠEKERIJA M, IVANKOVIĆ D, VULETIĆ S Coll Antropol 36 (Suppl 1) (2012) 9. — 17. MAZZI B, Problem financiranja obiteljske zdravstvene zaštite u Hrvatskoj. In:Proceedings (Sedmi kongres Hrvatskog društva obiteljskih doktora, Hrvatskog liječničkog zbora, Rovinj, 2007). - 18. LITTLE P, SLOCOCK L, GRIFFIN S, PILLINGER J, Br J Gen Pract 49 (1999) 806. — 19.VITALE K, 
DŽAKULA A, ŠULJIĆ P, TODOROVIĆ G, VULETIĆ S, ČOVIĆ A, Coll Antropol 33 (Suppl 1) (2009) 165. - 20. BRBOROVIĆ O Association of formal education and pressure for changing health habits to self-perceived mental and physical health, Doctoral thesis (2010) Accesses 19.7.2011. Available from: URL: http://medlib.mef.hr/753. - 21. JOHANSSON K, BENDTSEN P, AKERLIND I, Eur J Public Health, 15 (2005) 615. — 22 PELLETIER-FLEURY N, LA VAILLANT M, SZIDON P, MARIE P, RAINERI F SICOTTE C, Health Policy 83 (2008), 268 - 23. NOORDMAN J, VERHAAK P, VAN DULMEN S, BMC Fam Pract, 11 (2010) 87. — 24.
PATTON R, STRANG J, BIRTLES C, CRAWFORD MJ Emerg Med, J 24 (2007) 529 - 24. MZSS, Programi i projekti 2004-2007., Accessed 15.6. 2011. Available from: URL: http:/ /www.mzss.hr/hr/content/download/ 2475/21542/ file/MinZdravstvaProgramiProjekti20042007.pdf-13. - 25 . HZJZ, Preventivni pregledi osoba starijih od 50 godina, Accessed 21.6 2011. Available from: URL: http://www.hzjz. hr/publikacije/prevent_2007. pdf. -26 . Zakon o ograničavanju uporabe duhanskih proizvoda ( $\overline{\mathrm{N}} \mathrm{N}$ br. 125/08), accessed 15.6.2011. Available from: URL: http://narodne-novine.nn.hr/clanci/sluzbeni/ 2008_10_125_3560.html.

\section{Crnica}

Zagreb Emergency Medical Center, Heinzlova 88, 10000 Zagreb, Croatia e-mail:vcrnica@gmail.com

\section{SAVJETOVANJE O BIHEVIORALNIM KARDIOVASKULARNIM RIZICIMA UNUTAR SUSTAVA ZDRAVSTVA}

\section{S A Ž E T A K}

Breme nezaraznih bolesti, uključujući i kardiovaskularne bolesti, moglo bi se za do $80 \%$ smanjiti eliminacijom četiriju zajedničkih bihevioralnih čimbenika rizičnih za njihov razvoj (uporaba duhana, tjelesna neaktivnost, nezdrava prehrana i štetna uporaba alkohola). Pružatelji primarne zdravstvene zaštite u jedinstvenom su položaju unutar sustava zdravstva koji im omogućuje da smanjenju razvoja kardiovaskularnih bolesti aktivno doprinose pružajući individulano savjetovanje. Cilj je ovog istraživanja pokazati promjenu u učestalosti i djelotvornosti savjetovanja između dva razdoblja: razdoblju do 2003. te razdoblju između 2003. i 2008. Dobiveni rezultati unutar CroHort studije pokazuju da je učestalost savjetovanja niska, a ishodi savjetovanja nepoželjni. Ovime se ukazuje na nedostatak dosljednosti u preventivnom djelovanju unutar sustava zdravstva. 